\title{
HUBUNGAN POLA DIET MAKANAN BERBASIS KEDELAI DENGAN KELUHAN GANGGUAN MENOPAUSE
}

\author{
Yuniastuti, T. dan Cristiana, A. ${ }^{1}$ \\ STIKES Widyagama Husada
}

\begin{abstract}
ABSTRAKS
Menopause is the process of cessation of menstruation permanently because of aging the ovary that is influential on secretions of estrogen, progesterone, and prostaglandins. Menopause result in condition vasomotor, cardiovascular, psychological and sexually will influence the quality of life woman. This condition necessary repairs through setting a diet of foods containing fitoestrogen an alternative as a substitute for estrogen natural.

The purpose of this study is to see how the influence of soy-based food diet by female age group 51- 70 years against disturbances of menopause, especially disorders of cardiovascular disease by the method of Menopausal Rating Scale (MRS).

This research using methods interview open observation lapangan kuisioner by method and menopausal rating scale. Data analyzed by employing correlation pearson through spss aid program.

The results of data analysis of respondents indicated that there was no significant influence between consumption of especially food dna-based soybean with impaired complaint menopause. It is caused by the presence of factors of who also affecting, namely nutrition status, a disease that suffered and physical activity that is performed. The conclusion is consumption of especially food dna-based soybean only paid little influence against the minimization of disorder, complaints menopause because there were of factors of who participate in influence.
\end{abstract}

Keywords: menopause, complaint disorder menopause, food DNA-based soybeans menopausal rating scale 


\section{ABSTRAK}

Menopause adalah proses berhentinya menstruasi secara permanen akibat adanya penuaan ovarium yang berpengaruh pada sekresi estrogen, progesterone, dan prostaglandin. Menopause berakibat pada kondisi vasomotor, kardiovaskuler, psikologis dan seksual yang akan berpengaruh pada kualitas hidup wanita. Kondisi ini perlu dilakukan perbaikan melalui pengaturan diet makanan yang mengandung fitoestrogen sebagai alternative pengganti

Tujuan penelitian ini adalah untuk melihat bagaimana pengaruh pola makan makanan berbasis kedelai oleh wanita kelompok usia 51 - 70 tahun terhadap keluhan gangguan menopause terutama gangguan penyakit kardiovaskuler dengan metode Menopausal Rating Penelitian ini menggunakan metode wawancara terbuka, pengamatan lapangan dan kuisioner dengan metode Menopausal Rating Scale. Data dianalisis dengan menggunakan korelasi Pearson melalui bantuan program SPSS.

Hasil analisa data responden menunjukkan bahwa tidak ada pengaruh yang signifikan antara konsumsi makanan berbasis kedelai dengan gangguan keluhan menopause. Hal ini disebabkan karena adanya factor - factor yang ikut mempengaruhi, yaitu status gizi, penyakit yang diderita dan aktivitas fisik yang dilakukan. Kesimpulannya adalah konsumsi makanan berbasis kedelai hanya sedikit memberikan pengaruh terhadap minimalisasi gangguan keluhan menopause, karena ada factor - factor yang ikut mempengaruhi.

Kata kunci: menopause, keluhan gangguan menopause, makanan berbasis kedelai, Menopausal Rating Scale.

\section{PENDAHULUAN}

Menopause adalah kondisi dimana terjadi berhentinya menstruasi secara permanen. Penyakit kardiovaskuler merupakan salah satu penyebab kematian pada wanita postmenopause di Negara berkembang. Perbedaan antara insiden penyakit kardiovaskuler pada wanita pre- dan post menopause berada pada kerja estrogen endogen pada system kardiovaskuler dan terutama pada sel endothel vaskuler. Endothel berperan penting dalam homeostasis kardiovaskuler, yaitu melalui pengaturan tonus vaskuler, atau melalui pengaturan koagulasi dan respon inflamasi (Maturana, et al., 2007).

Wanita menopause mengalami gejala gangguan menopause yang dapat mempengaruhi kualitas hidup. Pada penelitian terdahulu, subjek penelitiannya adalah wanita dengan range usia 51 - 60 tahun dan dibagi menjadi 2 grup besar, yaitu grup pre menopausal dan post - menopausal. Pada kelompok usia pre - menopausal, 42 orang dari 97 subjek penelitian menderita gangguan jantung, dan pada kelompok usia post - menopausal, 50 orang dari 78 subjek penelitian menderita gangguan jantung. Hasil penelitian ini menunjukkan bahwa ada peningkatan yang signifikan jumlah wanita post menopause yang mengalami gangguan jantung (Elsabagh dan Abd. Allah, 2012).

Estrogen berperan sebagai antioksidan karena kesamaan strukturnya dengan vitamin E. Produksi radikal bebas endogen normal mempunyai dua peran 
yang berlawanan, yaitu dapat memberikan efek yang menguntungkan dan merugikan. Dalam kondisi fisiologis, terjadi keseimbangan antara jumlah produksi radikal bebas dan status antioksidan. Tetapi jika keseimbangan ini hilang, dan terjadi produksi radikal bebas yang berlebihan, maka dapat menimbulkan kondisi patologis. Salah satunya adalah terjadi peningkatan lipid peroksidasi dan kerusakan integritas membran; kerusakan pada protein dan DNA mitokondria dan inti sel. Sistem antioksidan mencegah dan menghentikan reaksi radikal bebas (Persky, et al., 2000). Stres oksidatif muncul ketika terjadi over produksi ROS. Efek antioksidan yang diberikan oleh estrogen melalui mekanisme peningkatan aktivitas catalase, SOD, glutathione peroxidase, dan glutathione reductase (Liu, et al., 2006).

Intervensi secara nutrisi dalam mengatasi gangguan menopause perlu dilakukan. Alternatif makanan yang bisa dikonsumsi untuk mengurangi gangguan menopausal adalah dari golongan Leguminase (kedelai). Golongan kedelai ini mengandung fitoestrogen. Fitoestrogen adalah bahan kandungan dari tanaman yang memiliki sifat seperti estrogen. Fitoestrogen biasanya memiliki struktur non steroid dan dapat meniru atau bersifat antagonis terhadap kerja estrogen endogen, dimana fitoestrogen dapat secara kompetitif berikatan dengan estrogen reseptor dalam organ reproduksi dengan memiliki afinitas yang lebih rendah (Tamaya, 2005).

Efek protektif vaskuler dari fitoestrogen kemungkinan dimediasi via penghambatan langsung dari proliferasi sel otot polos vaskuler melalui reseptor estrogen pada sel otot polos vaskuler.
Dehydrodaidzein yang merupakan fitoestrogen dengan aktivitas agonis yang kuat terhadap estrogen reseptor. Beberapa studi menunjukkan bahwa estrogen menghambat proliferasi sel otot polos vaskuler dan mencegah respon neointimal terhadap jejas. Estrogen reseptor berada di sel endotel dan sel otot polos vaskuler (Shen, et al., 2006).

Studi pengaruh pola makan wanita usia 40 - 51 tahun terhadap keluhan menopause perlu dilakukan karena hal ini berpengaruh terhadap kualitas hidup wanita, yang pada akhirnya dapat mempengaruhi produktifitas sumber daya manusia Indonesia. Penelitian ini akan meneliti tentang pengaruh pola konsumsi makanan berbasis kedelai dengan adanya keluhan gangguan menopause terutama gangguan penyakit kardiovaskuler. Hasil penelitian ini diharapkan dapat memberikan gambaran pola konsumsi masyarakat untuk makanan berbasis kedelai terhadap keluhan gangguan menopause khususnya penyakit kardiovaskuler, yang nantinya dapat mempengaruhi kualitas hidup wanita. Penelitian ini bertujuan untuk melihat pengaruh pola makan makanan berbasis kedelai oleh wanita kelompok usia 51 - 70 tahun terhadap keluhan gangguan menopause terutama gangguan kardiovaskuler dengan metode Menopausal Rating Scale (MRS).

\section{METODE}

Penelitian ini dilakukan pada 3 wilayah kerja Puskesmas Di Kota Malang, dengan jumlah responden sebanyak 100 orang. Variabel bebasnya adalah pola konsumsi makanan berbasis kedelai dan variable terikatnya adalah gejala keluhan pada 
menopause. Hasil dianalisa dengan korelasi Pearson dengan $\alpha=0.05$.

\section{HASIL DAN PEMBAHASAN}

Hasil penelitian diperoleh dari 100 responden. Sebagian besar responden mengkonsumsi makanan berbasis kedelai, yaitu tahu dan tempe, sebagian juga ditambah dengan susu kedelai.

Hasil analisa data secara statistik dengan Pearson Correlation menunjukkan bahwa konsumsi makanan berbasis kedelai tidak memberikan pengaruh yang signifikan terhadap gangguan keluhan menopause. Hal ini bisa dilihat dalam grafik 1 yang menunjukkan tren data pada 100 responden
Hasil uji korelasi Pearson menunjukkan nilai 0.011 dengan toleransi kesalahan $\alpha=0.05$. Hal ini menunjukan tidak adanya pengaruh yang signifikan antara konsumsi makanan berbasis kedelai dengan gangguan keluhan menopause.

Hasil wawancara juga menunjukkan bahwa responden juga mengkonsumsi makanan sumber protein hewani. Selain itu, ada beberapa responden yang memiliki penyakit seperti diabetes, dan hipertensi.

Berdasarkan hasil wawancara, beberapa responden juga masih memiliki aktivitas fisik yang cukup aktif. Responden yang memiliki aktivitas fisik yang cukup aktif, ternyata memiliki keluhan yang minimal.

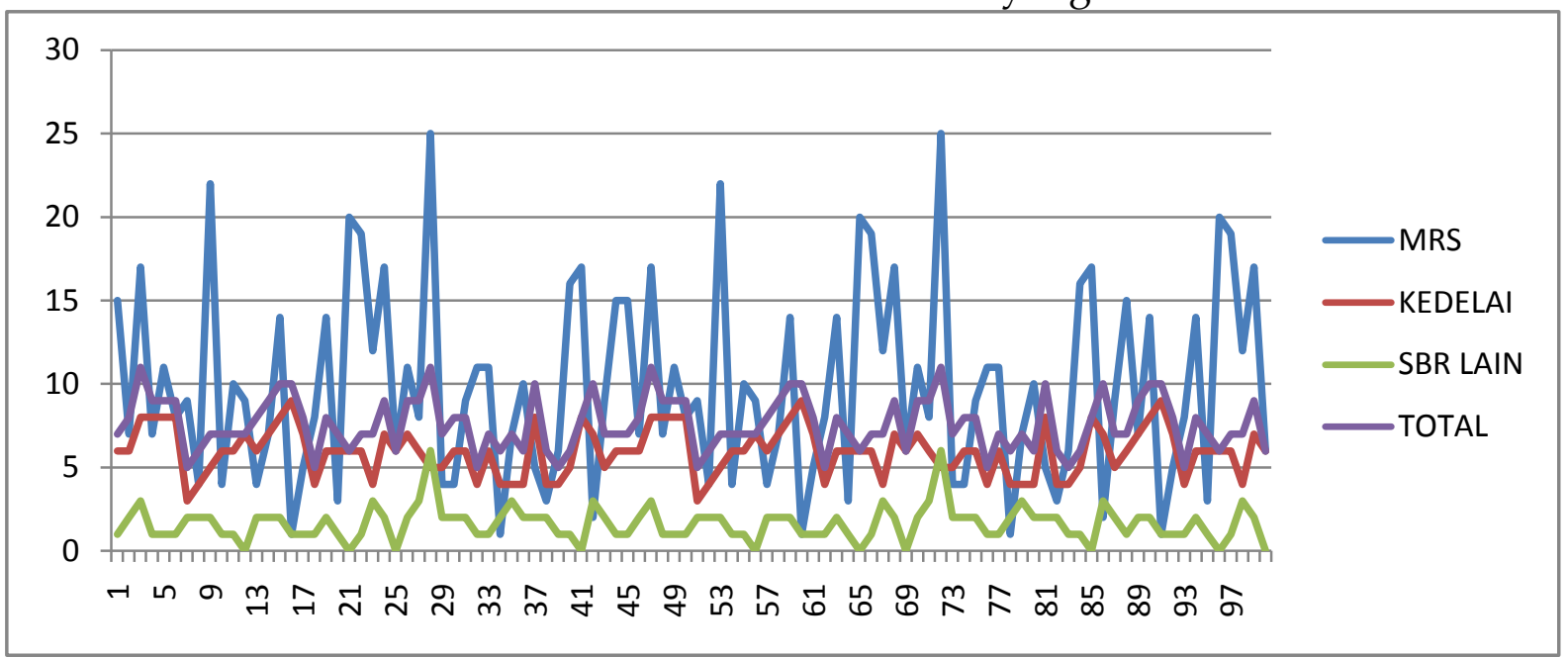

\section{Gambar 1 .Tren data pada 100 responden.}

Fitoestrogen yang berasal dari asupan makanan dapat mengurangi keluhan yang ditimbulkan pada saat menopause. Pada saat menopause, kandungan estrogen endogen mengalami penurunan yang signifikan. Sedangkan tubuh memerlukan estrogen endogen, yang berperan sebagai kardioprotektif dan mengatur beberapa mekanisme tubuh.

Konsumsi makanan berbasis kedelai tidak memberikan pengaruh yang signifikan pada gangguan keluhan menopause, kemungkinan disebabkan oleh adanya beberapa factor yang ikut mempengaruhi berat ringannya gangguan menopause. Faktor - factor ini diperkirakan adalah status gizi, penyakit yang diderita oleh responden, dan aktivitas fisik yang dilakukannya.

Pola konsumsi masyarakat sebagian besar mengkonsumsi tahu dan tempe secara rutin setiap hari dengan tambahan susu kedelai. Hanya sebagian 
kecil yang mengkonsumsi daging dan susu sapi karena factor ekonomi.

Beberapa responden menderita penyakit hipertensi. Hal ini sejalan dengan peningkatan prevalensi penyakit kardiovaskuler pada wanita menopause tidak hanya disebabkan oleh penurunan level estrogen endogen, tetapi juga karena terjadi penurunan ekspresi estrogen reseptor. Gangguan pada sistem kardiovaskuler ini akan menimbulkan terjadinya disfungsi endotel (Vita dan Kenney, Jr., 2001).

Sebagian besar responden juga mengkonsumsi sumber protein hewani, yaitu susu dan daging sapi. Asupan gizi dari protein hewani dan nabati ini akan meningkatkan status gizi dari responden. Selain itu, adanya perbedaan pola hidup dan tingkat pendidikan ikut memberikan pengaruh terhadap pilihan pola asupan gizi.

\section{KESIMPULAN}

Hasil penelitian ini menunjukkan bahwa konsumsi makan berbasis kedelai hanya memiliki sedikit pengaruh dalam meminimalisasi gangguan keluhan menopause. Hal ini disebabkan oleh adanya factor -faktor lain yang ikut mempengaruhi, yaitu status gizi, penyakit yang di derita dan aktivitas fisik yang dilakukan.

\section{DAFTAR PUSTAKA}

Albertazzi, P. 2005. Phytoestrogen in human health: What are the evidences. Curr. Med. Chem.Immun., Endoc, \& Metab. Agents. 5 : 141-148.

Barret-Connor, E., Ettinger. B., Hendrix, S., 2002. A comprehensive approach. Best Clinical Practice Ch. 13. The International Position Paper On Women's Health and Menopause. National Lung, Heart, and Blood Institute. USA

Elsabagh, E. E. dan Abd Allah. 2012. Menopausal symptoms and the quality of life among pre/post menopausal women from rural area in Zagagic city. Life Sci J. 9(2): $283-291$.

Erlandsson, M.C., Islander, U., Moverare, S., Ohlsson, C., Carlsten, H., 2005. Estrogenic agonism and antagonism of the soy isoflavone genistein in uterus, bone, and lymphopoiesis in mice. APMIS. 113: 317-323.

Kijkuokool, P., Parhar, I.S., Malaivijitnond, S., 2006. Genistein enhance N-nitrosomethylureainduced rat mammary tumorigenesis. Cancer Letters. 242: 53-59.

Loose, D.S. dan G.M. Stancel. 2006. Goodman and gilman's the pharmacological basis of therapeutics, $11^{\text {th }}$ edition. Ch. 47. Estrogens and progestins. Editor: L. Brunton dan J. Lazo. McGrawHill. New York.

Liu, H., Zang, C., Zeng, W., 2006. Estrogenic and antioxidant effects of a phytoestrogen daidzein on ovarian germ cells in embryonic chickens. Domest. Anim. Endocrinol. 31: 258-268.

Persky, A.M., Green, P.S., Stubley, L., Howell, C.O., Zaulyanov, L., Brazeau, G.A., Simpkins, J.W., 2000. Protective effect of estrogens 
against oxidative damage to heart and skeletal muscle in vivo and in vitro. PSEBM. 223 : 59-66.

Maturana, M.A., Irigoyen, M.C., Spritzer, P.M. 2007. Menopause, Estrogens, and Endothelial Dysfunction: Current Concept. Clinics. 62(2) : 77 $-86$

Mendelsohn, M.E. dan R.H. Karas. 1999. The protective effects of estrogen on the cardiovascular system. $N$. Eng. J. Med. 340(23): 1801-1811.

Mishra, G, D dan D. Kuh,. 2012. Health symptoms during midlife in relation to menopausal transition: British prospective cohort study. British Med J. 344

Shen, J., White, M., Husband, A.J., Hambly, B.D., Bao, S., 2006. Phytoestrogen derivatives differentially inhibit arterial neointimal proliferation in a mouse model. Eur. J. Pharmacol. 548:123128.

Setchell, K.D.R dan A. Cassidy. 1999. Dietary isoflavone: Biological effects and relevance to human health. J. Nutr. 129:758S-167S.

Tamaya, T. 2005. Phytoestrogens and Reproductive Biology. Reprod. Med. Biol. 4 : 225 - 229.

Tham, D.M., Gardner, C.D., Haskell, W.L., 1998. Potential health benefits of dietary phytoestrogens:
A review of the clinical, epidemiological, and mechanistic evidence. J. Clin. Endocrinol. Metab. 83:2223-2235.

Wassmann, S., Baumer, A.T., Strehlow, K., van Eikels, M., Grohe, C., Ahlbory, K., Bohm, M., Nickenig, G., 2001. Endothelial dysfunction and oxidative stress during estrogen deficiency in spontaneously hipertensive rats. Circulation. 103:435-441.

Vita, J.A dan J. F. Keaney, Jr., 2001. Hormone replacement therapy and endothelial function. The exception that prove the role?. Arteriol. Thromb. Vasc. Biol. 21:1867-1869. 